\title{
NEGLECTED TURNER SYNDROME IN A SHORT STATURED ADOLESCENT: CASE REPORT
}

\author{
Oluwayemi I.O ${ }^{\star, \dagger, 1}$, Odeyemi A.O ${ }^{2}$, Ayeni T.O ${ }^{3}$ \\ ${ }^{1}$ Department of Paediatrics, Faculty of Clinical Sciences, College of Medicine, Ekiti State University, Ado-Ekiti, Ekiti State, \\ Nigeria \\ ${ }^{2}$ Department of Paediatrics, LAUTECH Teaching Hospital, Osogbo, Osun State, Nigeria \\ ${ }^{3}$ Department of Paediatrics, LAUTECH Teaching Hospital, Osogbo, Osun State, Nigeria
}

DOI: https://doi.org/10.15520/ijmhs.v9i4.2556

Accepted 1 Apl 2019; Received 1 Mar 2019; Published Online 1 May 2019

\begin{abstract}
Turner syndrome, a chromosomal anomaly with loss of all or part of one sex chromosome, has an incidence of $1 / 2500$ female live births. Clinical signs like lymphoedema during infancy, or short stature and delayed puberty are common reasons to screen for Turner syndrome. Ovarian failure occurs in almost all affected females. We present a 15 year old girl who presented with short stature and delayed puberty. Her mother remembered she noticed swelling of both hands and feet during infancy but made no meaning of it. Patient's weight and height were below the $3^{\text {rd }}$ percentile and had no secondary sexual characteristics at presentation. Patient's karyotype $(45, \mathrm{XO})$ confirmed the diagnosis. She had low serum estradiol, small uterus and atretic ovaries. Puberty was stimulated with Primarin for 2 years during which she gained $3 \mathrm{~kg}$ in weight, $4 \mathrm{~cm}$ in height and breast development from Tanner stage 1 to 4 . Clinicians need to look out for common clinical signs of Turner syndrome for early diagnosis, referral and management of affected children for optimal growth and development.
\end{abstract}

Key words: Turner syndrome-adolescent-neglected-short stature

\section{INTRODUCTION}

Turner syndrome, a chromosomal anomaly in which there is loss of all or part of one sex chromosome, occurs in one out of every 2500 female live births [1]. Lymphoedema of the hands and feet is the most common reason to screen for Turner syndrome during infancy while short stature is the commonest presentation during childhood and adolescence [2]. They also commonly present with delayed puberty [1] and primary amenorrhoea in late adolescence and early adulthood. Growth failure, which the most common abnormality in Turner syndrome, begins prenatally and poor growth is often clinically evident within the first 3 years of life such that untreated adult is about $20 \mathrm{~cm}$ shorter than the average normal population [3-5]. In Turner syndrome ovarian failure begins by $18^{\text {th }}$ week of gestational age and rapidly progresses to fibrous degeneration of the ovarian follicles [6]. Serum FSH and LH which show a rise during infancy and early childhood gradually decline until 6 years of age and then rise again at the normal age of puberty [7]. Almost all of them eventually show sign of ovarian failure with only

\footnotetext{
* Corresponding author.

$\dagger$ Email: dareoluwayemi@gmail.com.
}

few able to achieve spontaneous puberty/ menarche and spontaneous pregnancies occur in $2-5 \%$ of Turner syndrome especially those with mosaic karyotypes [8-10].

\section{CASE REPORT}

We present OC, a 15 year old girl who presented with short stature and delayed puberty. She was a product of term gestation. Mother noticed swelling of both hands and feet soon after delivery but made no meaning of it and no medical intervention was sought because her growth appeared apparently normal during infancy and early childhood. Her mother however became bothered about absence of secondary sexual characteristics and conspicuous short stature compared to her peers hence the presentation in the Paediatric endocrinology clinic. Essential findings on examination revealed small for age female adolescent, not acutely ill looking, had a small for age weight of $40 \mathrm{~kg}\left(<3^{\text {rd }}\right.$ per-centile), and height of $1.38 \mathrm{~m}\left(<3^{\text {rd }}\right.$ percentile). Mother's height was $1.60 \mathrm{~m}$ while estimated father's height was $1.90 \mathrm{~m}$; the mid parental height was $1.69 \mathrm{~m}$ and the target centile range was $1.61-1.77 \mathrm{~m}$. She had wide carrying angle, widely spaced prepubertal nipples. She had normal volume pulses, 


\section{NEGLECTED TURNER SYNDROME IN A SHORT STATURED ADOLESCENT: CASE REPORT

synchronous, no radio-femoral delay, blood pressure of $90 / 60 \mathrm{mmHg}$, heart rate of 120 beats/minute, only the first and second heart sounds were heard with no murmur.

An assessment of Turner syndrome with delayed puberty was made. She had a reduced bone age compatible with 8 years of age. Pelvic ultrasound showed small for age uterus but the ovaries were not visualized presumably due to hypoplasia or atresia. Karyotype $45 \mathrm{XO}$ confirmed the diagnosis of Turner syndrome (Figure 1). Serum hormonal assay showed low estradiol $22.2 \mathrm{pg} / \mathrm{ml}(30-350 \mathrm{pg} / \mathrm{ml})$, high FSH $70.4 \mathrm{mmol} / \mathrm{L}(3-22 \mathrm{mmol} / \mathrm{L})$ and high $\mathrm{LH} 23.4 \mathrm{ng} / \mathrm{ml}(0.9-$ $1.05 \mathrm{ng} / \mathrm{ml})$. She was commenced on hormone replacement therapy using Primarine $0.15 \mathrm{mg}$ alternate days for one year, then increased to $0.3 \mathrm{mg}$ daily the second year and $0.625 \mathrm{mg}$ daily the $3^{\text {rd }}$ year when she was referred to the Gynaecologists for continued management having exceeded the age limit for Paediatrics. She attained steady growth and development of breasts and pubic hairs from Tanner stage 1 to Tanner stage 4 ; her height and weight also increased from $1.38 \mathrm{~m}$ to $1.42 \mathrm{~m}$ and $40.0 \mathrm{~kg}$ to $43.0 \mathrm{~kg}$ respectively during the two years period of hormone replacement therapy with remarkable improvement in her mood and general outlook.

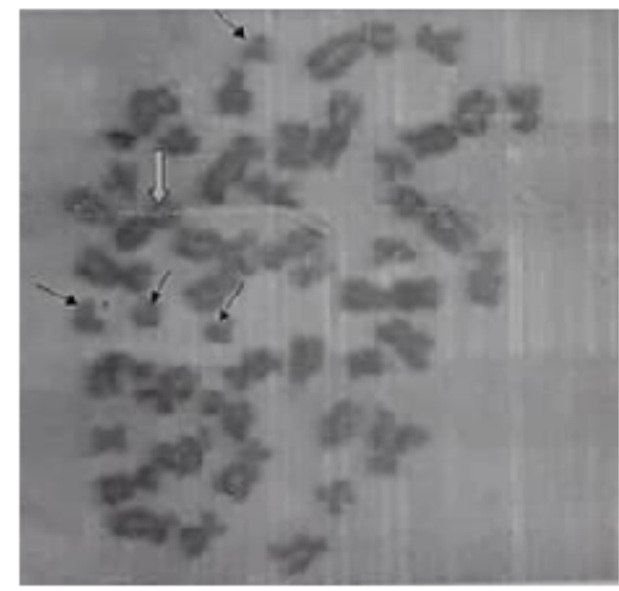

Figure 1. Karyotype: 45, XO

Chromosomes were examined from the whole blood cells cultured full term. The Chromosomal Sex of the patient is Female as the arrows indicate the 4Gs. The block arrow indicates the $\mathrm{X}$ chromosome.

\section{DISCUSSION}

Turner syndrome, if diagnosed early can benefit from growth hormone therapy which could help optimize their growth potential before induction of puberty in the majority of affected children who failed to enter puberty spontaneously. Clinicians in developing countries with limited diagnostic facilities can reliably make diagnosis of Turner syndrome using clinical signs that are very common in Turner syndrome patients from fetal life in utero to adolescence. Ultrasound finding of increased nuchal translucency or cystic hygroma in a fetus can predict Turner syndrome in $30-70 \%$ cases [11]. Lymphaedema of the hands and feet is the most common (97\% of cases) presentation in infancy while short stature is more common ( $82 \%$ of cases) during childhood and adolescence [12]. Clinicians need be aware of these early clinical signs and use them for prompt referral of suspected cases for definitive diagnosis and multidisciplinary specialist management. The index patient manifested clinical features suggestive of Turner syndrome in infancy but were neglected until she was 15 years of age after suffering needless emotional and psychological trauma. She achieved remarkable progress in development of secondary sexual characteristics within two years of hormone replacement therapy and appreciable linear growth with commensurate psychological and emotional boost. She continued to make progress as she looks and feels more like a matured female adolescent and she continued her management with the Gynaecologists.

\section{CONCLUSION}

Turner syndrome has notable clinical signs that can help clinicians suspect the syndrome in-utero (by ultrasonography), during infancy, childhood and adolescence. These should be used to aid early diagnosis and referral for specialist management and optimal growth of affected children.

\section{REFERENCES}

[1] Stochholm K, Juul S, Juel K, Naeraa RW, Gravholt CH. Prevalence, incidence, diagnostic delay, and mortality in Turner syndrome. J Clin Endocrinol Metab 2006;91:3897-3902.

[2] Gravholt CH. Clinical practice in Turner syndrome. Nat Clin Pract Endocrinol Metab 2005;1:41-52.

[3] Davenport ML, Punyasavatsut N, Gunther D, Savendahl L, Stewart PW. Turner syndrome: a pattern of early growth failure. Acta Paediatr Suppl 1999;88:118-121

[4] Ranke MB, Pfluger H, Rosendahl W, Stubbe P, Enders $\mathrm{H}$, Bierich JR, Majewski F Turner syndrome: spontaneous growth in 150 cases and review of the literature. Eur J Pediatr 1983;141:81-88.

[5] Davenport ML, Punyasavatsut N, Stewart PW, Gunther DF, Sa"vendahl L, Sybert VP Growth failure in early life: an important manifestation of Turner syndrome. Horm Res 2002;57:157-164.

[6] Pinsker JE. Turner syndrome: updating the paradigm of clinical care. J Clin Endocrinol Metab. 2012; 97(6):E994-E1003.

[7] Fechner PY, Davenport ML, Qualy RL, Ross JL, Gunther DF, Eugster EA, Huseman C, Zagar AJ, Quigley CA. Differences in follicle-stimulating hormone secretion between 45,Xmonosomy Turner syndrome and 45,X/46,XX mosaicism are evident at an early age. J Clin Endocrinol Metab 2006;91:4896-4902.

[8] Bannink EM, van Sassen C, van Buuren S, de Jong FH, Lequin M, Mulder PG, de Muinck Keizer-Schrama SM. Puberty induction in Turner syndrome: results of oestrogen treatment on development of secondary sexual characteristics, uterine dimensions and serum hormone levels. Clin Endocrinol (Oxf) 2009;70:265-273.

[9] Pasquino AM, Passeri F, Pucarelli I, Segni M, Municchi G. Spontaneous pubertal development in Turner's syndrome. Italian Study Group for Turner's Syndrome. J Clin Endocrinol Metab 1997;82:1810-1813. 
[10] Mortensen KH, Rohde MD, Uldbjerg N, Gravholt CH. Repeated spontaneous pregnancies in $45, \mathrm{X}$ Turner syndrome. Obstet Gynecol 2010;115:446-449.

[11] Alpman A, Cogulu O, Akgul M, Arikan EA, Durmaz B, Karaca E, Saðol S, Ozkinay C, Ozkinay F Prenatally diagnosed Turner syndrome and cystic hygroma: incidence and reasons for referrals. Fetal Diagn Ther 2009;25:58-61.

[12] Gravholt CH. Clinical practice in Turner syndrome. Nat Clin Pract Endocrinol Metab 2005;1:41-52.

\section{AUTHOR BIOGRAPHY}

Oluwayemi I.O Department of Paediatrics, Faculty of Clinical Sciences, College of Medicine, Ekiti State University, Ado-Ekiti, Ekiti State, Nigeria

Odeyemi A.O Department of Paediatrics, LAUTECH Teaching Hospital, Osogbo, Osun State, Nigeria

Ayeni T.O Department of Paediatrics, LAUTECH Teaching Hospital, Osogbo, Osun State, Nigeria 